R. Ilbstórta, Siło l’aulo, n. 129-131, p. 179-208, ago.-dez/93 a ngo.-dez./94.

\title{
DE COMO SE OBTER MÃO-DE-OBRA INDÍGENA NA BAHIA ENTRE OS SÉCULOS XVI E XVIII
}

\author{
Maria Hilda Baqueiro Paratso*
}

\begin{abstract}
RESUMO: O ubjetivo deste irabalho é analisar a polflica indigenista e as praticas adotadns nas capitanins dn Bahia, libeus e Porto Seguro entre os séculus XVI e XVII e as tentativas de conciliaģa dus interesses conflitantes entre grupos inufigenas, colonos, jesuftins e administradores metropolitanos. A nossin preocujaşio central é demonstrar como as relaçóes sociais estabelecichs resulıamm de visúes, interesses, referências culturais, valores e estratégias suciais dos vatrios agentes envolvicks e como essas diversidales se articularam, lecench uma recke social complexa relacionado com $\infty$ vários projetos pensadus quanto a efetiva ocupaçio e exploraçấ da nơva colónia.
\end{abstract}

palavras-citave: Perfodo Colonial, Bahia, Política indigenista, Máo-de-obra indigena, Escravidio indigena.

"A terra queimará e haverá grandes círculos brancos no
céu. A amargura surgirá e a abundância desaparecerá. A
terra queimará. A época mergulhará em grandes traba-
lhos. De qualquer modo, isso será visto. Será o tempo da
dor, dlas lágrimas e da miséria. É o que está para vir."
(Profecia Maia sobre a chegada dos europeus - Livro de
Chilan Balan de Chumayel:125; apud Romano; 1989:69).

I-As múltiplas visöes de um noro mundo: a terra e seus habitantes

A "descoberta" da América suscitou discussōes sobre verdades estabelecidas e consagradas como definitivas pela intectualidade da época. lam desdc a caracterização da nova terra como a antípoda, essencial ao equilfbrio físico da Orbis Terrarum, até à visão do paraíso reencontrado.

Os primeiros momentos podem ser caracterizados como de deslumbramento. $O$ aspecto luxuriante da cobertura vegetal, a abundancia de rios, frulos, animais e riqueza reforçavam a idéia expressa por Caminha: "cm se

\footnotetext{
- Professora do Depastamento de Antropologia da UFBA e Duuloranda pela FFLCHIUSP.
} 
PARAlSO, Maria llikta Bimpueiro. De como se obter máu-de-obra indigena na Bahia entre os séculus XVI e XVIII.

plantando tudo dá". Esta imagem ira, aos poucos, se allerando à medida em que as dificuldades de sua colonizaçāo c exploraçīo vão se concretizando no cotidiano dos colonos.

Também as imagens sobre os habitantes iniciam-sc pelo encanlamento e terminam ou convivem com as de horror. Inocentes, puros, não preocupados com riquezas, corpos bonitos, livres, hospitalciros, expressōes tão comuns em Caminha, Colombo, Vespúcio - sociedade sem propriedade privada, harmoniosa, sem reis, religião, palícios ou f́lolos - c as afirmaçōes de Pietro Martire d'Anghiera, que os classifica como os únicos sobreviventes da Idade de Ouro, formam uma imagem positiva dos fndios.

A contra-visão lambém encontra seus arautos: Nicolau Varré bárbaros e desonestos, ignorantes de Deus, sem preocupaçōes, vivendo segundo os seus instintos -; Yves d'Evreux; Anlonio Pigafetla; Jean A. de Saintonge; Jean Parmentier; Ulricl Schmidel; Gabritl Suares de Souza c Gandavo (HEMMING, 1978: 1-22).

Apesar das imagens serem oposlas, ambas caracterizam-se pela despreocupação com os delalhes e individualizações. São arquétipos e lipos absolulos que oscilavam de acordo com valores morais maniqueíslas, calcados na percep̧̧ão do concreto e do abstrato; do sagrado e do profano como um continum!m. Foi o conhecimento crescente que levou à percepção das diferenças, porém ainda nĩo individualizadas. As imagens ainda são globalizantes, ordenando a realidale em categorias genéricas e sua Iransformação decorre da alteraçăo do conjunlo das relaçōes sociais estabelecidas entre observador e observado (PINTO, 1992:51-53). Neste conlexto de mültiplas imagens em mutação é que deveınos enquadrar as discussōes que se desenvolveram nas metrópoles sobre a legalidade ou não da escravidão desses povos.

A versão paradisíaca, que será apropriada pelos poucos segmentos que irão se opor à escravidão, não dava a necessária sustentaçīo à legaliuade da prálica escravista. Por serem considerados não como inliéis, mas como filhos Jo paraiso, expressōes espontâncas da nalureza primiliva nāo conlaminada do homem, os indígenas da América não podiam ser enquadrados nos parametros do escravo, como eram pensados naquele momento histórico.

São as visões pessimistas e negalivas sobre as populaçōes indígenas que serão usadas pelos defensores da escravidāo, parlicularmente os colonos desejosos de acesso à mão-de-obra gratuila e abundante. Diante de imagens e interesses tão controversos, as posiçōes das metrópoles vão refletir indecisóes, tẹtativas de conciliação e busca de alternativas para a solução dos questionamentos e pressóes presentes quando da formulaçăo das políticas e do ordenamento jurídico das relações coloniais. 
Essas imagens controversas podem ser definidas como oposıas, porém, nāo necessariamente excludentes, mas complementares e específicas de acordo com cada situação vivida. Assim, o índio podia ser visto como participante na construção da sociedade e do sistema produlivo nas áreas em que as relaçöes de aliança predominavam; como trabalhador, nas regiões em que se processava a implantaçāo de atividades produlivas volladas para a exportação, o que pressupunha relações de dominaçäo mais eficientes no tocante à exploração do trabalho indígena; como povondor nas áreas de fronteiras e expansâo do dominio da Coroa; como ente selvagem, nas zonas de conflito, e como pagño, elemento constitutivo da natureza, quando vistos pela ética dos missionários.

A depender da posição do agenle e das suas múltiplas inserçōes no sistema social, as visōes opostas podiam estar presentes numa mesma análise e serem expressas por um mesmo autor a depender do enfoque e da situação a que se referisse.

\section{II-A realidade e o milo das primeiras relaçöes simétricas}

As formas explícitas de escravidão legalmente reconhecidas podem remontar ao ano de 1500 quando Pedro Álvares Cabral enviou índios como presentes a Gaspar de Lemos. A sua primeira interrupçăo efetiva ocorreu em 1755, quando da promulgaçâo do Diretório Pombalino. Retornou, setorialmente, a partir de 1808, quando uma série de Guerras Justas foram decretadas a vários grupos indígenas, como os Botocudo em Minas Gerais (1808), Bahia e Espírito Santo (1809), e aos Botocutos Meridionais (Kaingang e Xokleng) nos campos de Guarapuava e Curitiba (1808) e outros nos anos subseqüentes, principalmente no Malo Grosso e Amazonas (CUNHA: 1992:304). A nova proibição data de 1831, quando da Regéncia, e se manteve como decisão oficial até nossos đias.

Para melhor contexlualizarmos a escravidão indígena, devemos pensar a conquista e colonização pelo ângulo das idéias dos colonizadores. Para esses homens, o Brasil era a oportunidade através da qual poderiam obter poder, força, prestígio e riqueza aos quais não podiam acessar em Portugal. Boxer (1973) também chama à alenção para o afã de nobreza e crença na possibilidade de atingi-la no novo espaço e para o preconceito contra o trabalho manual como elementos que devem ser considerados nessa análise.

Nesse projeto de rápido enriquecimento, a questão da mão-de-obra era fundamental. Carentes de grandes capitais para investir, os colonos viam no trabalho indígena ạ grande solução, principalmente por sua abundância e a exigência de baixos investimentos para sua obtenção. 
PARASSO, Mntia Ililda Bayueito. De como se obter mãode-ubra indigena na Bahia entre os steulus XVI e XVIII.

A regiāo', que ć o objeto de nossa análise, era habitada em 1500 por grupos da família lingürstica Tupi-Guarani e da Macro-Je, conhecidos por Tapuias, alcunha que lhes fora atribuída pelos primeiros e que os portugueses mantiveram por muito tempo, inclusive, com toda a conotação pejorativa, indicando uma primeira percepção Jas diferenças, porém, ainda com caráter globalizante.

Se cruzarmos os estudos de lingüística, os dados arqucológicos e as referências históricas, só possíveis a partir do momento de contacto, podemos identificar os territórios dos vários grupos lingüísticos durante o período colonial. Queremos chamar atenção para o fato de o mapa, em anexo, indicar os territórios Iradicionais dos grandes grupos lingüísticos, que cram respeitados pelas outras tribos e que, quando invadidos, motivavam guerras. Não estamos, ainda trabalhando com a idenlificação/localização dos vírios subgrupos e nem com os segmenlos descidos e relocados em vazios demográticos provocados pelo deslocamento ou $\mathrm{em}$ áreas estratégicas pelos administradores coloniais.

Os referidos grupos da Camília lingüíslica Tupi-Guarani - Tupinambá e Tupinikin - ocupavam o litoral da regiño, sendo a ocupação recente, pois tinham migrado no sentido Norte-Sul no milênio anterior a descobrimento. Podiam, aiıda, ser encontrados no rio Paraguaçu - os Tupina - e no São Francisco - os Amoipirá e os Obakoatiara (URBAN; 1992: 20; OTT, 1988: 125; DANTAS; 1992: 444; PARAÍSO, 1992: 413).

Os Macro-Je, expulsos pelos Tupi do litoral, apresentavam grande diversidade lingüística, parecendo que essa regiăo fora o ponto de dispersão desse grupo a cinco ou seis mil anos alrás (URBAN, op cil: 20).

Um Jos mais numerosos era o dos Kiriri, que falavam quatro línguas diferentes: o Kipéa, entre os rios São Francisco c o Salitre; o Dzbukuá, no arco do submédio São Francisco; o Sapuyá, entre os rios Paraguaçu e Conlas; e o Kamamu, provavelmente na área interior da bafa do mesmo nome.

Nas áreas mais interioranas, entre os rios de Conlas e o Pardo, Jocalizavam-se os Kamakã-Mongoyó; entre o Pardo e o Doce, na mesma faixa, os Pataxó, Maxakali, Malali, Kutaxó, Kumanaxó, Kulatoi, Monoxó e Makoni. Em toda essa regiāo, na faixa intermediária, cntre esses grupos e os de língua Tupi, viviam os Aimoré/Gren/Bolocudos em progressivo deslocamento no senlido Norte-Sul refluindo do contato imposto.

1 A nossa análise corresponde às árens das antigas capi tanias da Bahia (cxcetunndo-se Sergipe del Rei), de lihéus e de Porto Seguro (exclutindo-se o seu limite sul, a regiño entre as tios Mucuri e S3o Mateus, hoje pertencente ao estado do Espírito Santo). 
R. Ilistórhn, Sâu Pautu, n. 129-131, p. 179-208, ago.-dez./93 a ago.-dez./94.

Havia, ainda, os grupos de língua isolada, como os Tuxá, Katembri e Natu, no baixo São Francisco, e os que se deslocavam do Piaú nos períodos de grande estiagem, como os Gueguê e os Akroá.

Os conflitos entre os grupos Tupi eram comuns e igualmente o eram entre estes c os Macro-Jê. Esıas oposiçöes e estado de guerra consıante foram usados pelos colonos no estabelecimento de aliänças, obtenção de mão-deobra, alravés da aplicação da regra Tupi de cunhadaço ${ }^{2}$, e na obtenção de "Índios de corda". Também os íncolas viam nos colonos a possibilidade de obterem aliados poderosos contra os seus inimigos Iradicionais e, ao mesmo tempo, lentarem preservar-se dos sallos ou assaltos, desviando a ação dos colonos para os grupos inimigos. Logo, podemos inferir que essas peculiaridades culturais dos grupos indígenas favoreceram as práticas de dominação e a construção de alianças surgidas a partir dos interesses dos colonos e dos próprios índios. Este quadro de composição de aliança, no entanto, era altamente fluido, compondo-se, rompendo-se e recompondo-se de acordo com a dinâmica das relaçōes eslabelecidas entre os segmentos sociais.

É nesta confluência e oposição de interesses que se iniciam os primeiros aprisionamentos paralelos à prática do escambo. Na verdade, o quadro das relaçōes estabejecidas compunha-se de relaçóes simulıâneas de comércio, aliança, guerras e escravidāo, numa allènáncia e conversão de acordo com os diferentes momentos e formas de contrato. Porém, os primeiros escravos nĩo se destinavam a ocupação ou colonização da nova colónia. Os prisioneiros cram enviados a Portugal e desconhecemos se eram destinados ao alivo comércio de escravos exercido por aquele país. A pequena quantidade enviada parece indicar que se destinavam mais a saciar a curiosidade metropolitana ou a serem símbolos de ostentaçāo de riqueza e prestígio de alguns privilegiados.

As Expediçōes Exploradoras, apesar das recomendaçōes em sentido contrário, costumavam enviar pequenas quantidades de calivos para Portugal. Porém, estes envios tinham um caráter assistemático e a crença dos indios de que eslariam sendo Iransportados para a casa de Maíra - a Terra sem Males, que se localizava milicamente onde o sol nasçe, após o grande rio, e que lodos os Tupi-Guarani desejam alcançar em vida - indicam na direção de que tais práticas não chegaram a abalar as relaçōes estabelecidas.

Já a criação das feitorias tornou as relações mais constantes e revelou as contradiçōes. Devido à fragilidade da ocupação e ao pequeno número de portugueses c seu desconhecimento do espaço a ser explorado, as relações

2 Cunbadıço: Conj. de obrigasũes que o irmâo da esposin de um homem tinha para com este e que inm desde atividudes económicas, sociais, políticas e guerreirns. 
PARAISO, Maria Hilda Baqueiro. De como se ubter mâu-de-ubra indigena na Bnhia entre os seculos XVI e XVIII.

assamiram um caráter preduminante calcado na troca de produtos da terra, inclusive o pau-brasil, por artigos manufalurados metropolitanos, principalmente ferramentas de metal. Essa prática já dalava de 1502, quando o monopólio da exploração do pau-brasil foi concedido a Fernão de Noronha. No cntanto, só com o estabelecimento das referidas feilorias, essas alividades passaram a ocorrer sistemalicamente.

As relaçōes de troca Ieriam sido relativamenle ben aceilas devido ao seu caráler aparentemente simélrico; ao atralivo exercido pelos novos produtos - embora estes começassem a criar dependencia para com os fornecedores e hierarquizaçōes internas entre os possuidores dos referidos objelos -; a abundancia da madeira e sua localização nas proximidades do litoral. Essas relaçōes de Iroca cram compatíveis com os padrōes culturais dos grupos Tupi, particularmente por serem exercidas tradicionalmente pelos homens (derrubada, transporte e troca), por manterem o caráter comunitário da produção, além de não interferirem de forma drústica no modelo de organizaçāo social, nas formas de Irabalho e na estruluração do tempo. Outro aspecto que deve ser destacado é o de que as trocas nāo pressupunham a imposição aos índios de uma nova visăo económica regida pelas leis de mercado. Para eles, o que ocorria era a continuidade das relaçōes de troca de excedentes, base da construção de alianças e mecanismos de solidariedade, que pressupunham estarem estabelecendo com os porlugueses (SCHWARTZ; 1988: 44).

O falo da escravidão vollar-se para o envio dos apresados para Porlugal não lhes permitia ter plena consciência dos termos impostos pelos porlugueses que nāo podem ser, caracierizados como de aliança e solidariedade. A Nova Gazeta do Brazil inlormava que, acompanhando as toras de pau-brasil, os navios Iransportavam levas de "rapariguinhas e rapaziuhos" (DORNAS FILHO; 1939: 13-14). E não eram apenas os porlugueses que exerciam essa atividade. Em 1531, na área da futura capitania de lthéus, na baía de Camamu, Martin Afonso de Souza desbaralou o comercio de Francisco de Chaves e aprisionou um navio espanhol carregado de centenas de escravos Tupinikin $^{3}$ (MALHEIROS, op cit:202; HEMMING; op cit: 35).

Assim, podemos constatar que o período, ao qual tradicionalmente nos referimos como sendo de relaçōes simétricas e de escambo, na verdade, já se

3 Alé esse momento, a discusstó sobre a escrivictio ainht nifo havia se efetivado em Purtugil. Rresente na Esmonta a prtir de 1511 e agravach pelas denúncias de Bartolumé dé Las Casas em 1514, a primeim orientaçio emanath de Roma é a Bula de 28/04/1537 de Puulo III, que tecunbecin a humanictule dus indios e proibia a sun excravizasto por nío serem infieis (DAVIS, 1968: 156-157; MALLIEJROS, 1944: 205). Purem devido à rengües dus colonos que se sentinm nmeagnulos ante a possibilichide de se verem

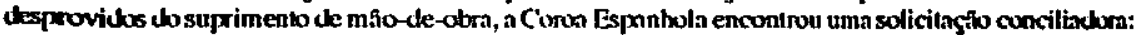

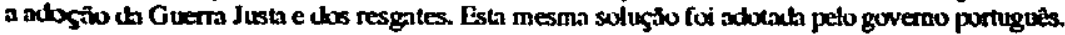


R. Illstiorta, Sio Paulo, n. 129-131, p. 179-208, ngo.dez./93 a ngo.-dez./94.

caraclerizava pela existência de relação assimétricas e de escravização dos grupos Tupi do litoral. $O$ que o lorna peculiar é o fato dessas relações de escambo predominarem no Brasil, pois os escravos eram enviados para Portugal, mascarando as relaçōes eslabelecidas. Pórém, o projeto de efetiva ocupação c colonização, introduzido por Martin Afonso de Souza, era incompatfvel com a poslura dos índios de considerarem tais relaçóes como esporádicas e regidas pela preocupação com o eslabelecimento de aliança, o que levou a superaçño dessas relaçōes sociais, como veremos a seguir.

\section{III - O projeto de eferiva octupação e as mudanças definitivas das relaçöes interétnicas}

Um novo período de relações vai ser estabelecido a partir da implanlação das Capilanias Heredilárias. Porém, podemos constalar determinadas continuidades cntre os dois períodos. O primeiro deles é que o contato ainda vai estar restrito aos grupos Tupi do litoral. O segundo é a convivência das relações de escambo, já mais resırilas, com a prálica de envio de escravos para Porlugal. Isto, aliás, já eslava agora legalmente instiluído, como se pode observar, por exemplo, no Regimenlo da Sesmaria concedida a Pero de Góes, que the permilia enviar "dezessele peças de escravos" por ano nos navios que mandasse a Portugal, além de poder "cativar gentios para seu serviço e dos navios" e vendê-los em Lisboa. Caso não ulırapassasse a cota anual, estaria, inclusive liberado do pagamento de siza (MALHEIROS, op. cit: 203; DORNAS FILHO, op. cit: 15-16).

Porém, a grande inovação é a de que a escravidāo ${ }^{4}$ passa a ser massiva e os aprisionados começam a ser destinados, ma sua quase tolatidade, à

4 O grande idteúlogo un escrnvidîo indigena em Portıgal foi Álvaro Pais, fmnciscano, que transpos us principios da Guerrn Justa nos Mourus jmm as relaģues instituflas no Brasil. As bases do seu racioćnio canclerizavam a (ittern Justa como aquela a) em que preexistisse açăo injusta do adverśírio; b) que fusse decretala por auluridale competente; c) que fosse decretach com bons intenģues. Estes principios fornm reformulacks entre 1539 e 1.542 por um attor não identificado, que incorporou as idéias de Santo Agostinho e Sto Tumás de Aquino. Os novos critérios adolndus por Portugal prissam n ser: a) decretação por aụtoridade competente, excluílb o Pap dessi relaçäo; b) a justeza (ta causa da decretnģo deveria ser consideratla correta pelas alltorichdes reconhecichns; $c$ ) as intençäes dos solicitantes teriam que ser avaliadns como boas pelas referiths autoridades (PERRONE-MOISÉS: 1992:1 15). Com o mssar (h) tempo, algumas altemçôes, que poikemos identificar como acréscimo, redtugies ou mudanģas quanto is formas de decretaçio ou controle de Guerras Justas, foram

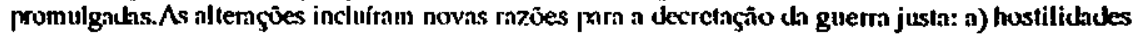
prévias; b) opusiçáo à atunçâo dos unissionárius; c) impedimento ao livre comércio; d) prótica dn antropofagia (PERRONE-MOISÉS, op. cit: 123-127). Com a impusiçî́o de restriçües à dectetaçî́ 
PARAISO, Maria IHilda Bayueiro. De como se obler máu-de-obra indigena na liahio entre us seculus XVI e XVIII.

implantação da efetiva ocupaçāo e colonização do Brasil, baseadas, preferencialmente, na produção agrário-exportadora açucareira. E para yue tal ocorresse, havia a necessidade de ajuslar a mäo-de-obra a um novo ritmo de Irabalho e sua inserçño compulsória no novo sistema produtivo, gerando os primejros grandes conflitos. Agora já nāo se tralava de ilusão da viagem para a Terra sem Males, além do grande rio. Era o aldeamento e sedenlarização forçados e a escravidão na própria terra.

A competiçāo entre vários segmentos sociais porlugueses (colonos e contratadores reais) e entre estes e os tranceses, que estabeleciam a aliança com alguns grupos indígenas, $\mathrm{e}$ desinteresses dos índios pelos antigos objetos oferecidos, o que os teria levado a exigir armas de fogo c oulros equipamentos para continuarem a manter relaçóes de troca, colocaram os primeiros óbices às relaçóes de escambo. A crescente autonomia Jos colonos com relação aos produtos de subsistência também criava o desinteresse pela continuidade do sistema. Outros falores decorriam da posiç̧̄o do f́ndios, para os quais, como já afirmamos, as relações de troca não eram regidas pelas leis de mercado, tendo, portanto, um caráler esporádico, que não satisfazia à nova realidade (SCHWARTZ, op. cit: 44; HEMMING, op. cit: 37).

Outro aspecto a ser considerado é que o escambo näo cra visto da mesma forma pelos traficantes e pelos povoadores. Para estes, o escambo cra uma estratégia de dominação baseada na implemenıação de um cstado de crescente desestruturação social e incapacidade de satisfação das necessidades de produção e reprodução social das comunidades indígenas nos moldes Iradicionais, gestando as condiçōes necessárias à implementaçāo das novas relaçōes de trabalho.

As novas relações de incorporaçño compulsória do Irabalhador ́ncola, além de implicarem na desestruturação e inviabilização da sobrevivéncia do sistema organizacional dos grupos indígenas, lambém violava a divisão do trabalho tradicional das sociedades Tupi. Enquanto os colonos desejavam o concurso da mão-de-obra masculina para as atividades agrícolas, os homens aceilavam realizar, apenas, as tarefas de derrubadas e queima. As demais

Guerra Justa e as alteraçũes chs relaçües interétnicas, novas alternativas furam buscadas fara a obtenção legal dus escravos, como a compra de "índios de Corta" ou resgatalos - aqueles que (embora nem sempre) teriam sido feitus prisioneiros por tribus inimigns e seriam destinados a rituais antropofágicos. Assim como enm comuns as acusaģes da ausêneia de justiça no dectetaģio dn Guerra Justa (vide a introxluçấo dn Lei te 20/3/1570), tendo sido algumas delas formalmente consideradas ilegais apés jâ lerem ocorridu (o que so beneficiou os poucos subreviventes identificados e localizadus), também a prílica dos resgates é cercada de acusaçües quanto a manipulaçues feitis pelos colonos parn a obtençio de mîu-de-obra utilizada (PERRONE-MOISÉS, op. cit: 128). 
R. Illstörta, Sĩo Paulo, n. 129-131, p. 179-208, ago.-dez./93 a ago.-dez./94.

atividades, por serem atribuídas às mulheres, eram rejeitadas, o que não era compreensível, ou aceilável pelos colonos. Também a crescente consciência da unilateralidade dos direitos, só garantidos aos portugueses, e dos deveres cobrados aos índios, começa a despertar sua consciência de que a suposta aliança, que eles imaginavam ter estabelecido com os colonos, não se constituía uma realidade ordenadora das relaçōes. O desrespeito à lógica interna de sua sociedade, levava-os a questionar os benefícios da suposta aliança, principalmente quando a emergente necessidade de māo-de-obra passou a exigir que os cativos, destinados aos rituais antropofágicos, fossem entregues aos porlugueses o que provocava reaçóes tanto dos caplores quanto dos capturados. Para que lal comércio ocorresse sem ser pela coerção, exigiria toda uma reestruluraçāo dos valores e crenças dessas sociedades. Também ocorriam insatisfaçōes devido às crescentes exigências da entrega dos excedentes para a troca, quando parte deles, deslinava-se, tradicionalmente, ao provimento das Expediçöes guerreiras, essenciais à reprodução do modelo social Tupi.

Outras razöes tornavam a nova forma de trabalho inaceitável para o grupo. Uma delas era a ruptura das suas formas de organização do sistema produtivo e do consumo, que não se baseava nos moldes portugueses, mas numa concepção comunitária, na qual a preocupação com a formulação da solidariedade e das alianças era o elemento ordenador; e inviabilizar a reprodução social do grupo por não dispor do tempo necessário para as práticas tradicionais. A solução encontrada foi a criação de aldeamento com trabalhadores compulsoriamente engajados. Esses aldeamentos eram, inicialmente, instalados nos espaços onde se localizavam as aldeias. Porém, de forma crescente, adquiriu-se o hábito de transferir os índios para locais considerados mais adequados aos interesses e necessidades dos colonos. Além da vantagem de manter a māo-de-obra em locais de fácil e rápido acesso, o deslocamento dos índios dos seus territórios de origem era uma garantia de que as novas relaçōes seriam mediadas pela organização da produçăo e pelo sistema de dominação que thes era imposto.

Há um silêncio quase absolulo sobre a localização das propriedades que, comprovadamente, usavam escravos indígenas. Apenas dispomos dos cálculos relativos à área compreendida entre o castelo da Casa da Torre, $\mathrm{em}$ Bom Jesus de Tatuapara, hoje conhecida como praia do Forte, ao norte de Salvador, e seu limite Sul, a ponta do Padrão, no período que antecede a inslalaçĩo do Governo Geral (MARIANI, 1971:1-5). Porém, pode-se inferir que as relaçōes não eram pacíficas se considerarmos os relatos, pedidos e o destino dos Donatários das três antigas capitanias que estão em tela, e que não é muito diferente dos demais. 
PARASSO, Maria Ililda Bayueiro. De como se obter mâu-de-ubra indigena na Bahia entre us séculos XVI e XVIII.

O crescimento da população porluguesa no litoral colocava $\mathrm{em}$ cheque a aliança antes estabelecida. O produto da troca oblido pelos colonos não salisfazia as novas necessidades. Embora a questão da subsistencia cosse razoavelmente satisfatória, o trabalho sistemálico exigido nas novas atividades nâo conseguia ser resolvido pelo sislema de troca c aliança, inclusive por exigir transformaçōes radicais ná organizaçĩo social e economica dos grupos indigenas. Por oulro lado, os índios, saltisfeila a curiosidade pelos novos objetos, resistiam às imposiçōes, inclusive quanto à forma e objetivo das guerras e ao desvio dos prisioneiros dos riluais de antropofagin. O uso das guerras inter-tribais en benefício dos inleresses dos colonos - oblençĩo dos "f́ndios de corda" - encontrava aí um limite que, $\mathrm{cm}$ alguns casos, conseguia ser superado por um novo lipo de aliança: ou os f́ndios accilavam sua condição de infermediários na oblençīo de calivos com novas finalidades que não rituais, ou participavam de sallos, sob o comando de portugueses a grupos inimigos. Porém, esła situaçĩo indicava o yue viria a seguir: uma série de revoltas que se espalhavam por lodo o litoral da colonia.

É como resultado dessas Iransformaçōes que o Donatário da Bahia enfrentou a revolta dos Tupinambá, e terminou por ser ritualmente sacrificado na ilha de Itaparica. Os Tupinikim de Ilhéus e Porto Seguro, após terem se aliado por longo período aos colonos que ali haviam se inslalado, lambém se revoltaram pelo constante desrespeito à sua idéia de aliança, queimando as vilas e engenhos, e levando à fálência as duas capilanias.

Essa situação, principalınente a ação dos Tupiuambá da capilania da Bahia, influenciou de forma Jecisiva a elaboração do Regimento do Primeiro Governador Geral, como veremos mais adianle.

As revoltas sucessivas nas várias capitanias, levando-as à faléncia c a perda de vidas e inveslimentos, exigiam mediclas por parte da Coroa. Essas relaçōes conflituosas a a aliança de índios com franceses, obrigaram-na a uma intervenção, visando criar as condiçōes necessárias ao controle dos íncolas e garantir aos Donalários o apoio necessário para efetivarem a ocupação e colonização das terras. Era o encerramento de uma ctapa na qual os Donalários contavam, apenas, com seus esforços, conlingenles e recursos para fazerem frente à sua grande ameaça: os "indomáveis" indigenas que, em levas sucessivas, atacavam, queimavam e malavam. Eles cram a real ameaça ao projeto de ocupaçāo e colonizaçāo e isto vai ficar claro na ação dos primeiros governadores.

É também nesse período que as relaçōes entre fndios e colonos assumiram a forma que irá caraclerizá-las dấ em frente: coerção e reação. A razão dessa nova situação decorre não só dos diferentes pontos de visła dos portugueses e dos índios com relação ao traballo e a produção, 
R. Ilestúrka, Săo Paulu, n. 129-1.31, p. 179-208, ago.-dez./93 a ago.-dez/94.

comoindica Schwariz (op cir: 42), mas lambém do conjunto de cventos e processos pré-coloniais que formavam a base da ação dos Tupi ante a situação historicamente nova - a conquista - e a incorporação das experiências adquiridas a partir da nova realidade que thes era imposta, como destaca Monteiro (1992:126).

\section{IV - A centralizaçäo das aģöes de repressäo e o domínio dos Tupi da costa}

O Regimento de Tomé de Souza é a primcira peça legal na qual esta explicilada a política da Coroa Portuguesa". É nele, também que se estabelece a dupla polftica de conciliaçāo/liberdade para alguns grupos indígenas e de repressão/escravização para outros. Declara-se que o principal objetivo do povoamento É a "propagação da fé católicán", atrair os índios à paz e aumentar a população. Proibia-se saltear c fazer guerra aos nativos sem a ordem expressa do Governador e de pralicar sallos a aldeias, o que vinha provocando revolta e guerra. Para as tribos inimigas era recomendado que se thes fizessem guerra, "desıruindo as aldeias e povoaçóes, matando, cativando e fazendo execular nas próprias aldeias alguns chefes que puider aprisionar..." (MALHEIROS, op cit: 213:214).

É a lentativa de ordenar as relações de colonos e fundios de forma que a política da Coroa - ocupar e colonizar - se tornasse possível, interrompendo o caos vivido até entāo. $\dot{E}$ interessanle ressallarmos que, para melhor

PERRONE-MOISÉS (op. cir: 117), diferentemente dus demais autores que tralarnm a questāo, identifica lógica e coerência nos a parentes nvanços, recuus e contradjçues da legislaçâu indifgena porluguesa. E esta identificaçâu lorna-se possivel quanclo se percebe os eixos du raciocinio dn metrópole. Primeiro devemus destacar que huuve leis de cunho genérico e outras de caráter es. pecfficu e até lucalizadas espacinlmente. $A$ nrticulaçío entre as várias leis nôo pode ser percebida sem que se desinute o alcance e o objetivo de cach uma delas. $O$ outro eixo de raciocínjo e que precisn ser articulado au anterior mra que compreendhmos $\mathbf{c}$ identifiquemos sua tógica, $\epsilon$ a entegoriznçđo atribufda aos grupos indigenas com os quais os colonos entrnvam em contato e o lipo de relaşăo estabelecila entre os dlois segmentus. Assim, poxlentos identificar duas grandes calegurias: a dos "mansos/aldeadus/aliados"e n clos "bravios/ermntes/inimigos". E em funçio in calegorização atribulda au grupve ha capacichule de convencimento dos colonos quanto a "ferocichue" Jeste, que a Coroa determinava a polfítica a ser adotadn. As linhas mestras e gerais definiram parn os "mansos" o direito à liberdade, garantia ths terras ocupactes, aldenmento, trabalho remunemulo e proteçĩo. Sĩo mra estes grujpos as leis e constantes recomendaçues de respeito a suas terrns, da renfirmaçāo no direito ì liberdade e ch exigência de "bons tratos" e respeito. A grande alegaçîo ern de que deles dependiam o sustento e a defesa da colônia. Ja parn os "bravios", a legislaçto reservava tratamentu diferenciack: Guerra Justa, escravidūo, descimentos for. gados, recomenthģio e autorização para uso da força e alé o direito de matá-tos, principalmente aos bomens em "ichde de guerri". 
PARAIso, Maria Hilda Baqueiro. De como se obter mfto-de-abra indígena na Bahis entre os seculus XVI e XVIII.

efetivar tal política de orientação dupla, a Coroa envia com o primeiro Governador, aqueles que se tornaram, daí para a frente os arautos e defensores de tal política: os jesuítas.

A atuação de Tomé de Souza pode ser caracterizada mais como tentativa de conciliar que de reprimir, apesar da morte de alguns caciques na boca de canhöes em Salvador. Isto nos indica uma preocupação em reduzir os conflitos, estabelecer alianças e fortalecer a estrutura governamental, além de criar um cinturāo de segurança em volta das vilas e povoaçōes com o assentamento de grupo aliados nas suas proximidades. Porém, não deixou de deslocar aldeias todas as vezes que considerava importante, como para a construção de conventos para os jesuítas, carmelitas e do Desterro no perímetro da cidadela de Salvador (HEMMING, op. cit: 80 ).

Porém, é a partir de sua atuação e de seus sucessores que se inicia a ocupação de novos espaços conquistados aos indígenas, sendo o grande centro difusor a cidade de Salvạor e seu Recóncavo. É também nesse período que a prática dos "saltos" às aldeias deixa de ser realizada na capitania do interessado e passa a ser feita nas vizinhas, como forma de burlar - controle do Governador. As denúncias contra essa prática eram constantes, pois os Donatátios sentiam-se prejudicados pela atuação dos vizinhos (SCHWARTZ, op. cit: 47; HEMMING; op. cit: 39-41).

Esta situação foi denunciada por Pero de Góes, em 07/02/1550 e confirmađa por Nóbrega em 05/07/1559. As razōes da queixa dos Donatários devia-se a ação de um colono que havia enganado um cacique aliado, que sempre atuara como intermediário na obtenção de "índios de corda" e que terminara por ser aprisionado e vendido, provocando revolta entre os membros de seu grupo. Porém o apresamento era a única forma de garantir o acesso à mão-de-obra indígena nos moldes e rapidez desejados. As formas predominantes para a obtenção desse suprimento era a compra dos "índios de corda", o que implicava no estímulo às guerras inter-tribais para a "criação" de prisioneiros, através da implementação de saltos. $O$ uso dos conhecimentos das inimizades intertribais e intergrupais foi um elemento essencial para manipulação dessas relaçöes.

Os assaltos alteraram a estrutura das guerras nativas, inserindo-as numa nova lógica - a dos colonizadores - regida pelas pressões e demandas crescentes. Também a transformação do cativo em escravo e nāo em prisioneiro destinado ao sacrifício ritual, era uma exigéncia que provocava reaçöes. A crescente agressividade nas formas reativas provocava a maior violéncia por parte dos colonos, criando um círculo fechado de violência crescente de ação-reação e um clima de guerra permanente, manifestando as contradiçōes existentes nas relações estabelecidas. 
R. Histórhn, Sĩo Paulo, n. 129-131, p. 179-208, ngo.-dez./93 a ngo.-dez./.44.

Este quadro pode ser percebido claramente já no governo de Duarle da Costa, quando as revollas assumem um caráler mais constante. Em Salvador ocorreu o ataque ao engenho do Cardoso e às fazendas de gado de Ilapoá. A represália, comandada pelo filho do Governador, destruiu cinco aldeias, matou índios, principalmente suas lideranças, escravizou os sobreviventes e distribuiu-os enlre os senhores de engenho do Recóncavo (MARIAN1, op. cit: 4-5; HEMMING; op. cit: 31).

Mas, é no governo de Mem de Sá que os problemas assumiram caráter mais dramático devido ao agravamento das relações com a expansão da economia açucareira. Também dalam desse período as grandes epidemias, problematizando ainda mais as relações sociais. $O$ despovoamento das aldeias e aldeamentos, as revoltas e a expansão dos movimentos messianicos, caracterizam esse período. Este quadro demonstrou aos colonos que o proje to dos aldeamentos jesuílicos, como solução para o problema de garantia de mão-de-obra, não era viável.

No primeiro momento, parece que leria havido apoio por parte dos colonos, que o consideravam como uma alternativa interessante: garantia a concentraçã̃o de grande densidade de Irabalhadores; era um mecanismo mais barato que o da realização do apresamento; liberava as terras através da concentraçăo e confinamento dos aldeados. Porém, com as epidemias, o modelo demonsirava sua fragilidade como produtor de excedentes apropriáveis e mão-de-obra. As epidemias e a alla taxa de mortalidade criavam un círculo vicioso que dificulıva a realizaçāo do projeto: a necessidade conslante de reposição de contingente nāo só o tornava mais vulnerável ao contágio e morte, como lambém, inviabilizava a qualificação do índio para as novas alividades económicas que deveriam exercer.

Como complemento a esse quadro, os descimentos promovidos funcionavam como veiculadores e difusores das epidemias que se espalhavam acompanhando os deslocamentos dos jesuílas, colonos e índios aldeados, e dos movimentos messianicos, que ficaram conhecidos pelo nome genérico de Santidades. Estes movimentos assumiram caráter extremamente forte no Recôncavo e no Baixo Recóncavo, envolvendo índios aldeados, convertidos e escravos foragidos. Uma das peculiaridades das Santidades era o seu cunho milenarista, uma das formas reativas à dominação portuguesa. Outra era o fato dos movimentos manterem uma série de padrōes culturais da tradição Tupi, como a liderança exercida por líderes carismálicos, no estilo dos antigos Karaíba. A repressão no caso da Santidade do Jaguaribe deu-se através de dois braços do poder colonial: a Visilação do Santo Ofício e a ação das Iropas do Governador, com a intermediação do mestiço Tomacaiuna, un elemento essencial no processo. A figura desse mestiço é na verdade, un 
PARAfSO, Maria Hilda Baqueiro. De cumo se obter mâu-de-abra indjgena na Babia entre us seculos XVI e XVIII.

símbolo do quadro das contradiçōes presentes no conjunto das relaçóes interéınicas no fim do Século XVI. As alegaçōes religiosas - heresia - foram a base da atuação do Santo Ofício. Questäo de segurança - foco de resistência à prática de aldeamentos e de alaques aos engenhos e vilas - cra o argumento usado pelo poder civil. Apesar da morle de um dos "Papas", em 1585, há notícias da irrupção de vários movimentos em outros pontos do litoral, sendo que no Recóncavo, a úllima nolícia é de 1627 (SCHWARTZ, op. cit: 54-56).

A política de Mem de Sí calcou-se nos princípios já estabelecidos em 1548: proleção aos convertidos, garantia de terras para seus aliados, estímulo para a criação de novos aldeamentos, valorização das lideranças aliadas; e repressão aos índios "inimigos". A sua aluaçĩo repressiva é de grande monta e voltada para os Tupinambá Ja capilania da Bahia; os Tupinae do vale do Paraguaçu; os Tupinambá dos rios Sergipe, ltapicuru c Real; os Kaelé de Alagoas, que foram descidos para o Recôncavo; os Tupinikin de llléus, Porto Seguro e rio São Maleus, onde perdeu seu filho; os Tamoio do Rio de Janeiro e os Poliguara da Paraíba (HEMMING, op. cit: 83-92).

As derrotas impostas por $\mathrm{Mem}$ de Sá aus Tupi do litoral criaram as condiçōes necessárias para a efeliva ocupação da costa c a estabilização exigida para o sucesso da ocupação e colonização. Os sobreviventes aceitaram aldear-se como uma das allernativas de sobrevivencia, o que gerou a aliança e o encanto entre o Governador e os jesuílas, inspirando o poema, em seu louvor, claborado por Jose de Anchieta, "De Gestis Mendi Saa", e a aceitação pelos inacianos da necessidade do uso da força como meio de promover o aldeamento e a conversão dos índios. Os resultados dessa aliança foram tão positivos que, durante o governo de Mem de Sá, a Companhia de Jesus aldeou trinta e quatro mil índios (HEMMING, op. cit: 100-107).

Porém, temos que considerar que outras cstratégias foram adolatuas por grupós ou subgrupos Tupi. Além dos movimentos de cunho milenarişa, aos quais já nos referimos, os silvícolas associavam seus conhecimentos e prálicas tradicionais às novas experiências c criavam novas formas de resistência ao avanço do domínio colonial. Dentre eslas, destacaremos as revoltas, as fugas para as matas interiores ainda não penetradas e a aceilação do papel de intermediários na escravização de outros grupos, o que thes oferecia uma proteção temporária contra o apresamento e os descimentos. Porém, o respeito a essa aliança pelós colonos sempre foi fluído e rípido.

A laxa de morlalidade e despovoamento dos aldeamentos inviabilizavam a continuidade do proje lo de evilar os conflitos e saltos. Entre $1559 \mathrm{e}$ 1560 ocorreu a primeira epidemia de varíola, que se difundiu a partir do Espírito Santo no sentido Norte, alingindo o Reconcavo entre 1561 e 1562. Calcula-se que tenham morrido trinta e seis mil índios aldeados no litoral, nāo se tendo idéia do número de mortos no sertão. Em 1563 foi a epidemia. 
R. IItstórls, Sĩo Paulo, n. 129-131, p. 179-208, ago.-dez./93 a ago.dez/94.

de sarampo que provocou novas mortes. As lenlativas desesperadas de suprir os contingentes através dos descimentos só agravava o quadro com a contaminação de novos grupos. Reforçava-se a idéia dos colonos de que os aldeamentos não eram solução para o problema da mão-de-obra, pois haviam se Iransformado num depósilo de indivíduos desestruturados cultura e socialmenle, doentes, desmotivados, morosos, improdutivos, incapazes, até mesmo, de se auto sustentarem.

Também a orienlação imprimida pelos jesuílas de transformar os aldeamentos em núcleos predominantemente voltados para a "conversăo do gentio" criava atritos quanto a utilizaçāo do aldeado como trabalhador. Era a contradição que se estabelecia entre dois modelos de colonização: um voltado para a exploração plena dos fatores produtivos e outro que priorizava a conversão, cujo fulcro central se materializava na administração dos aldeamentos e na destinação dos aldeados.

As opções dos colonos tornaram-se mais radicais: a busca de trabalhadores através dos descimentos e apresamento, particularmente, sob o argumento da necessidade da Guerra Jusia ${ }^{6}$. A pressão assumiu tais proporções que muitos índios optaram pela escravidão voluntária. Mas a quantidade disponivel, apesar dos descimentos, saltos e apresamentos, era insuficiente para a continuidade do modelo até então adotado. Duas soluções foram introduzidas: a imporlaçĩo de escravos africanos e as entradas para o sertão em busca de outros grupos indígenas para suprir os vazios demográficos. $\mathbf{E}$ um novo período que se inicia com as lulas com os Tapuias, a penetração dos sertōes e a expansão da ocupação/colonização, que começa, lentamente, a abandonar o litoral.

- Porém, apesar das inovações, as táticas de relacionamento entre índios e colonos vão ser mantidas, apenas com a eleição de um novo tipo de inimigo que podia ser apropriado - os grupos Macro-Jê do sertão: os Kiriri e os Aimoré/Gren/Botocudo, no primeiro momento.

\section{V-A nova fonte de suprimento: os Tapuia dos serfões}

Inicialmente gostaríamos de relembrar que os Tapuia, devido à incorporaçāo pelos colonos dos preconceilos desenvolvidos pelos Tupi, não eram

A legisfaçĩo subre Guerra Jusıa é profficun entre os seculos XVI e XVIl. Ampliando, realuzindo, controlamlo mais efetivamente ou mudundo os úgîus responsáveis por esse controle temos as leis 20/03/1570; 06/01/1574; 11/01/1595; 10/09/1611; 25/05/1624; 17/10/1655; 03104/1655; $0.9 / 04 / 1655 ; 03 / 04 / 1688$ e a de $25 / 10 / 1707$. 
PARASO, Maria HIilda Baqueiro. De como se obter mão-de-obra indigena na Babia entre os seculus XVI XVIII.

considerados como a opção ideal para substiluir os Tupi. Um conjunto de características cullurais desses grupos acentuava a sua rejeição, principalmente por serem tradicionalmente caçadores e colelores semi-nomades, o que os fazia corresponder ao imaginário europeu dos marginais: sem domicilio fixo, habitantes de espaços livres, naturais, sem senhores ou hierarquia social e, por isso mesmo, inúteis, pois, por nāo produzirem excedentes, nāo representavam qualquer benefício à coletividade. Devido também a essas características, eram considerados como mais ameaçadores à segurança, eslando, além do compreensível por náo sc enquadrarem no estatuto e na laxinomia social vigente na Europa. Como ilustralivo da nossa afirmativa, basta considerarmos as Jescriçóes dos cronislas e missionários sobre estes poyos, nas quais esses aspectos são ressaltados quase que de forma obsessiva ${ }^{7}$. O "serlão" em que habitavam lornara-se o novo espaço desconhecido sobre o qual se exercilava a imaginação coletiva: era o locus do horror e da riqueza que ali dormia, esperando ser descoberla.

É interessante, também, chamarmos atenção para o fato desses grupos terem habitado originalmente o litoral antes Ja expansão dos Tupi e que, regularmente, realizavam visilas no antigo habilat nos espaços intermediários entre as aldeias Tupi. O vazio demográfico criado pelos descimentos aldeamentos/confinamentos c despovoamentos, permitiram a intensificação desse fluxo para a costa. Porém, sua presença nĩo só criava atritos com os novos ocupantes como também lhes desperlava a consciência de que aqueles grupos poderiam subslituir os Tupi dizinados.

Outra referencia essencial para que compreendamos o conjunto de relações sociais estabelecidas após o contacto, é a de que o seminomadismo tem o caráler de uma circulaçấo sazonal num território com limiles definidos e reconhecidos pelos demais grupos e não um deslocamento desordenado por espaços nāo definidos. Além disso, diferentemente dos Tupi, esses grupos não tinham, entre suas tradiçōes, os hábitos migratórios dos Tupi. Daí porque dificilmenle optavam por abandonar seu habitat e refluir para as matas interiores como estratégia de resistencia, preferindo o enfrentamento armado, o que os tornava ainda mais ameaçadores para os portugueses.

O projeto inicial dos colonos era o de promover descimentos atraves da organização de Expediçōes ou do uso dos Tupi aliados para que fizessem cativos, que eram resgalados de acordo com a legislação vigente. Esses

7 As acusaçües de antroporagia, selvagetia, ausência de residência fixâ, agressividaule pơdem ser enconimdas nas Cartas Jesulticas, em Gôndavo e Gabriel Soares de Souza, apenas para nos res. tringirmus no mais conhecilus do século XVI. 
R. Jlistórta, Sĩo Paulo, n. 129-131, p. 179-208, ago.-dez./93 a ago.-dez./94.

deslocamentos forçados apresentavam uma série de vanlagens. Por desconhecerem o território em que eram aldeaclos e estarem cercados por inimigos tradicionais, reduzia-se a sua capacidade de resistência e oposição ao projelo de dominação, além de garanlir o suprimento de trabalhadores necessários nos locais onde a atividade econômica era mais aliva. Porém, também se estabelecia uma contradição de difícil superação: os novos cativos eram mais vulneráveis ao contágio, aumenlando a taxa de modalidade, exigindo novos suprimentos, acentuando a reação dos índios e a necessidade crescente de mais violência para obter novo suprimento de trabalhadores, que morriam logo que eram aldeados conjuntamente com os contaminados sobreviventes Tupi, fechando um círculo vicioso de difícil superaçāo. Apesar desses limites, foram trazidos, entre 1575 e 1576 , quatro mil índios de Sergipe; vinte mil da serra do Orobó (Kiriri), entre as bacias do Pardo e Contas, e oitocentos Poliguará da Paraíba e Pernambuco (HEMMING, op. cit: 52-53).

Monteiro (1990: 17) chama-nos atenção para o fato dos descimentos apresentarem restriçōes, se comparados às práticas anteriores: a) as distâncias a serem cobertas lornavam o acesso à mão-de-obra crescentemente oneroso; b) reduçāo da margem de lucro devido à maior taxa de mortalidade nos deslocamentos a longa distancia; $c$ ) os grupos Macro-Je ofereciam maior resistência aos descimentos e ìs guerras por não estarem fascinados por $\mathrm{e}$ dependentes de artigos manufaturados; d) devido às suas características culturais, exigiam maior tempo de aclimatação às novas atividades, implicando na depreciação do "arligo".

Os ataques dos Kiriri e Aimorés garantiam aos colonos os argumentos necessírios à obtençāo do direito de mover-Ihes Guerra-Justa. Nesta primeira etapa, o uso de índios guerreiros aldeados e de mamelucos era de vital importancia para o sucesso do empreendimento.

Aos poucos, o crescente conhecimento dos sertóes e a especialização na atividade de apresamento transformaram as expediçōes relativamente autonomas com relação aos índios pombeiros, que passaram da condição de aliados à de escravos.

Além da justificativa da necessidade de mover Guerra Justa, as expediçōes também usavam como argumento a busca de metais preciosos. Numa área que era o locus da imaginação e da esperança de enriquecimento rápido, os mitos da montanha de prata; el Dorado; Vapubassu; da terra das Amazonas e tantos oulros locais de riquezas minerais, eram comuns e justificavam as entradas, cuja a única riqueza exiraída era o índio descido.

Na Capitania da Bahia os primeiros combates e apresamento ocorreram no vale do Paraguaçu, seguindo o caminho das boiadas e a expansão das sesmarias dos grandes latifúndios, como os da Casa da Torre e dos Saldanha. 
PARAISO, Maria llilda Baqueiro. De como se obter māo-de-obra indigena na Bahin entre os séculus XVI e XVIII.

Os grupos atingidos foram, após a destruição dos Tupinaê por Men de Sá, os Kiriri-Sapuyá, os Maracá e os Paiaiá que eram descidos ou escravizados e distribufdos entre os parlicipantes e financiadores da expedição de forma proporcional aos financiamentos e responsabilidades de cada um (Provisöes Reais in ACIOLY e AMARAL: 1925: 64-76). Outras tálicas eram a de aldeá-los sob a adminisıração de parliculares ou de missionários capuchinhos e franciscanos, tranformando-os em "muralhas do sertāo", isto é, barrejras de aliados/domesticados que impediam os deslucamentos de oulros grupos ainda nāo controlados. Essas açōes se intensificaram a partir de 1591, sob a coordenaçāo de Gaspar Dias Adorno, após o [racasso do projelo de Gabriel Soares de Souza de construir Casas-Forles a cada cinqüenta léguas na regiño. Na verdade, ele só conseguiu construir uma, na serra do Guariru, que originou o aldeamento de Pedra Branca dos Kiriri-Sapuyá, hoje sede do município de Santa Terezinha (PARAÍSO, 1985; 1-10). Contra os Aimoré, a primeira decretaçāo de Guerra Jusı data de 1595, tendo as açöes se iniciado em 1597. Como tropa de combate auxiliar, foram deslocados os Poliguara da Parába, que os colonos exigiram que permanecessem na região após terem se encerrado os combates iniciais. Paralela à guerra, o jesufı Diogo Nunes procurava aldear os Aimoré em Ilhéus sem obler sucesso. O primeiro aldeamento do grupo só ocorreu em 1601. A guerra aos Aimoré envolveu as regiōes do Baixo Reconcavo, na capilania de llhéus, e a de Porlo Seguro (SOUTHEY: 1977: 271-275; SILVA CAMPOS, 1947: 104-105).

Essas duas frentes iniciais atraiam a atenção devido à importância económica e estratégica para a expansão da economia colonial. $O$ Vale do Paraguaçu era o caminho das boiadas que abasteciam a zona açucareira e o Baixo Recóncavo, garantia o fornecimento de generos alimentícios, principalmente as farinhas, madeira para as construçōes e as caixas de exporlação do açúcar. As queixas dos moradores dessa região - Cairu, Boipeba, Tinharé c Camamu - envolviam denúncias de desvio das verbas militares e tributos destinados a thes garantir proteção dos ataques dos índios e molivaram a criação da Casa da Relação da Bahia (Carta dos Moradores da Cidade da Bahia ao Rei in ACIOLY e AMARAL, op. cit: 114).

Novas epidemias entre os aldeados Kiriri e Aimoré recrudesceram as relaçöes e intensificaram as entradas em busca de reposição, desencadeando ataques a Maragogipe, Boipeba, Cairu, Tinharé, Capanema, Aporá, llapororoca, Cachoeira, Jaguaripe e Jequiriçá. Fechava-se, mais uma vez, o círculo de ação-reação-repressão, gerando um clima de guerra generalizada.

Um novo recrudescimento resultou da Carta Régia de 02/03/1651 que determinava o deslocamento dos Aimoré/Gren para combaterem os Paiaiá de Jacobina, compulsoriamente engajados na mineração de ouro. Também os 
R. Ilistórła, Siu Paulu, n. 129-131, p. 179-208, agu.-dez./93 a ngo.-dez./94.

Kamakã-Mongoyó c os Palaxó começavam a ser vistos como impedimento à abertura da rola do Serlão de Baixo, que era o caminho mais curto para as boiadas destinadas ao norte das Minas - Araçuraí e Serro Frio. Os Maracá, que até entāo haviam se mantido como aliados, aluando como intermediários nos apresamentos, também passaram a ser encarados como impedimento ao acesso ao rio Sāo Francisco pela rola central. As decretações de Guerras Justas se sucediam, assim como a construção de Casas-Fortes, acantonando soldados e índios aldeados para combaterem os revoltosos (BORGES DE BARROS; s/d 173-180).

Esse quadro de revoltas repressão/escravização convivia com as tentativas da Coroa, dos jesuílas e de Roma de reduzirem as possibilidades de se oblerem escravos indígenas, o que faz Álencastro (1992: 104) levantar a hipótese dessas medidas atenderem aos interesses dos traficantes negreiros.

As tenlativas de entregar a administração de todos os índios aos jesuílas (30/07/1609) havia redundado em revoltas e protestos dos colonos e na sua revogaçāo dois anos depois, quando se vollou a garantir o direito de obterem-se escravos através da Guerra Jusia e dos resgates. A Bula de 22/04/1639 de Urbano VIII, que condenava à excomunhão os que cativassem e vendessem índios; não chegou a ser aplicada no Brasil (MALHEIROS, op. cit: $240-242$ ).

No caso da Bahia, as tentativas de conciliação podem ser percebidas nas determinaçōes simultâneas do conde de óbidos de aldear revoltosos e autorizar Guerras Juslas. Em Carta Régia de 23/06/1655, o conde de Autoguia decretava Guerra Justa a todos os revoltosos das Capilanias da Bahia, linéus e Porto Seguro. Os primeiros a serem atacados foram os Paiaiá de Jacobina. Em 1657, os Marać́ da serra do Orobó e, em seguida, os Grến e os Kiriri de Cairu, Jequiriçá, llapororócas e Jaguaripe; os Kamakā-Mongóiọ e Pataxó de Maraú, rio de Contas, Serra dos Aimorés e onde mais fossem enconirados (BORGES DE BARROS, op. cit: 180).

Para efeluar uma ação de tal envergadura, o Governador realizou a contratação do primeiro paulista - Domingos Barbosa Calheiros - com a promessa de compensação com títulos honoríficos, terras e pagamentos pelos serviços.

Considerando que as constantes revollas indígenas decorriam da "bondade" com quem eram tratados, o Governador Alexandre de Souza Freire opla pelo enrijecimento das medidas a serem adotadas, como se pode observar no Termo de Assento da Casa de Relação da Bahia. Após relatar vários ataques e responsabilizar os índios pelos crimes de roubo, assassinatos, eslupros, antropofagia e da morte do comandante da Casa-Forte de Cairu, dois soldados, um cacique e alguns índios aldeados, num domingo, quando 


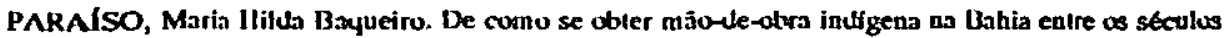
XVI e XVIIl.

saiam da missa, Souza Freire propōe novas medidas. Estriba-se nas Carlas Régias de 06/04/1643; 23/12/1654, confirmada pela de 23/06/1655 e de 20/12/1668, pela qual ficava autorizado a decrelar Guerra Justa nos termos que "Ihe aprouvesse", casligar o "gentio búrbaro" pelo seu "desaforo c alrevimento" com a "necessária brevidade", mandando degolar os homens em "idade de guerra" que resistissem e declarar cativos os que fossem aprisionados (SOUTHEY, op. cit: 322-323; ACIOLY e AMARAL, op. cit: 126).

As medidas adoladas foram: a) contratar paulistas experientes no combate aos índios b) autorizar a destruição das alueias e a distribuição das terras assim desocupadas; c) assolar as aldeias inimigas, colocando-as sob o regime de terror; d) nomear capitães-mores para cada campanha, exigindolhes relatos detalhados dos prejuízos provocados pelos índios e) usar o Assento de 1643 como única fonte de autorização de decretação da Guerra Jusı; f) Iralar com igual rigor os (ndios aldeados que houvessem apoiado ou se refugiado entre os revollosos (ACIOLY e AMARAL; op. cir:126). Podemos observar que os argumentos usados no Termo de Assento estavam de acordo com a legislaçāo vigenle: a Guerra Jusła era decorrência da necessidade de defender colonos e seus invesimentos, já que os indígenas eram considerados uma ameaça a segurança da Colonia.

A contralação de outros paulisıs foi providenciada, sendo-lhes garantido o pagamento de oito mil cruzados, Cornecimento dos aviamentos necessários, armas, índios combatentes, além do direito de manterem em legítimo cativeiro os prisioneiros de guerra e poder transferí-los para Sĩo Paulo às expensas da Fazenda Real. Atenderam a convocaçīo Estevão Ribei ro Baião Parente, Manoel Rodrigues de Arzão e Pascoal Rodrigues. Não nos deteremos nas questōes geradas por esses contratos e que envolveram a Conmara, o Governador, a Fazenda Real e os contratados devido ao não cumprimento do estipulado (vide ACIOLY e AMARAL, op. cit). Nem também analisaremos as resistências opostas pelos capitāes-mores quanto ao fornecimento de víveres, armas e índios aos paulistas (vide correspondência entre o Governador Furlado de Mendonça e os capitāes-mores in BORGES DE BARROS, op. cit: 184-186).

As açōes envolveram a regiño de Cáiru, vale do Paraguaçu, Jacuípe, Jequiriçá, Sño Francisco, Jacobina e Rio Real, atingindo grupos Gren, Kiriri, Maracá, Anaió e Paiaiá. O resullado da açāo foi milhares de prisioneiros, tendo sobrevivido poucos devido ao contágio por doenças infecto-contagiosas $\mathrm{c}$ à exaustão provocada pelas longas marclıas forçadas. $O$ maior número de sobreviventes foram os Maraća - mil e duzentos - que terminaram por ser vendidos em Maragogipe, pois nāo havia recursos para embarćí-los para São Paulo, como estipulava o contrato firmado. Comno decorrência, houve vários protestos por parte dos financiadores e compradores, que acusaram Estevão Baiño Parenle de estar 
R. Iftstórta, São Paulo, n. 129-131, p. 179-208, ngo.-dez./93 a ago.-dez./94.

negociando tribos aliadas a de ter aviltado o preço dos escravos indígenas queda de quarenta para dez cruzados -, o que terminou provocando uma reprimenda do Governador ao paulisla. (SOUTHEY, op. cit: 322; BORGES DE BARROS, op. cit: 173; ACIOLY C AMARAL, op. cit: 132; HEMMING, op. cit: 349-350; MONTEIRO, 1992: 62-63). Como já observamos anteriormente, a verdadeira razāo dessa depreciação do valor dos cátivos devia-se a laxa de morlalidade ser maior entre os grupos recém descidos e a necessidade de maior tempo para adequá-los às atividades exigidas, devido à sua tradição de grupos caçadores c coletores.

A crise com os capităes-mores do serlão só pode ser contornada quando lhes foram concedidos iguais privilégios expressos nos contatos dos paulistas. A alegaçāo era a de que por terem realizado as mesmas atividades nas suas regiōes não poderiam ser remunerados de forma diferente. $O$ primeiro a receber sesmaria, pagamento de soldo, concessāo da administração dos índios aldeados, lítulo de fidalgo e o Hábito de Cristo foi Joāo Peixoto Veigas, capitão-mor dos Paiaiá (ACIOLY e AMARAL, op. cit: 184-185; 231). Outros foram beneficiados, passando essas exigencias a comporem os novos termos dos conlralos estabelecidos.

Volpato (1985), ao analisar a crescente especialização militar dos bandeirantes, acenluada após sua contrałaçāo para a Guerra dos Bárbaros, em 1680 , quando o pagamento garantido pela Coroa passou a ser os acima referidos, demonstra como ocorreram essas mudanças na orientaçāo das atividades exercidas por esse segmento social. Transformados em força paramilitar particular disponível para a contratação por Governantes para combaler fndios, quilombolas e invasores estrangeiros, os bandeirantes abandonaram a busca de melais e o descimenlo de índios apresados para São Paulo nas proporçōes anteriores. A Coroa, dada a fragilidade das tropas governamenlais na colonia, criava mecanismo complementares de premiaçăo, além do pagamento e financiamento das açōes. Alguns tinham valor simbólico e significavam preslígio social: a concessão do Hábito de Cristo e o tílulo de fidalgo. Outros representavam a possibilidade de enriquecimento: doaçāo de sesmarias; pagamento de pensóes vilalícias e controle efetivo dos índios aldeados em decorrência da sua atuação. É desde então que os bandeirantes, ao invés de retornarem a São Paulo, transformam-se em grandes sesmeiros espalhados entre o Piaú e o alto São Francisco.

Essas concessões fizcram com que cada vez maior o número de pessoas se lançasse ao empreendimento de combater/aldear/administrar os grupos indígenas dos "sertões". Assim, reacendeu-se o conflito entre sesmeiros, capitāes-mores, criadores de gádo, missionários e índios. Uma das razões foi a prática adolada pelos referidos capitães de retirarem os aldeados das mis- 
PARAISO, Maria Ilitda Baqueiro. De como se obter mäu-de-obra indigena na Bahia entre us séculus XVI e XVIII.

söes para transformá-los em combalentes ao seu serviço, o yue lhe garanlia a expansão das terras ocupadas. elemento essencial para o lipo de alividade económica yue exerciam: a criação de gado no molde extensivo. Outro ponto de atrito era o inleresse dos sesmeiros em expulsar os f́ndios tos seus campos de criaçăo de gado, como veremos addiante.

A crise assumiu lais proporçōes que molivou a Provisão Real de $15 / 10 / 1679$, definindo compeléncias e direitos dos envolvidos na disputa. João Peixoto Viegas a Antonio Guedes de Brilo tiveram que restiluir os f́ndios que havia retirado das missöes. Em contraparlida, os missionários passaram a ser obrigados a ceder os aldeados loda a vez. que esles tossem solicitados pelos cápitáes-mores e receberam recursos c estímulos para a fundação dos novos aldeamenlos e missōes para os grupos da região. Com essa medida, objetivava-se o seu confinamenlo em áreas delimitadas, liberando as demais para expansão da ativiclacle pecuária.

Os connitos lambém envolveram os jesuílas que aluavam nos mesmos sertōes, particularmente, ná área de Jacobina, onde tiveram que aceitar a assistencia militar de Manoel de Castro Nogueira na adminisłração dos Paiaiá, em Natuba dos índios Kiriri e no São Francisco, onde cstavam aldeados os Anaió. Todos esses grupos, Iransformavam-se, assim em "harreiras do sertío", garantidures da expansāo da pecuária. Os conflitos com os missionírios acirraram-se de tal maneira que sua expulsão dos aldeamentos no São Francisco lornou-se inevitável. Nesta tiltima regiño, os jesuílas foram substiluf́los pelos terésios c estes pelos capuchinhos ilalianos. Esses aldeamentos lerminaram por ter suas terras incorporadas a patrimonio da Cása da Torre (ACIOLY a AMARAL, op. cit: 234-235; DANTAS, op. cit: 44.1: HEMMING, op. cit: 352).

É importante chamarmos altenção para o falo de que as atividades pecuárias, diferentemente do que afirmavam os historiadores ceonómicos, não linham qualquer interesse no concurso da mäo-de-obra indígena. $O$ interesse cra a lerra para a expansão do crialório. Isto implicava no afastamento dos primitivos ocupantes e na desıruiçấo dos campos de caça e colelá, elementos essenciais da conomia dos grupos Macro-Jê. A criaçăo extensiva exigia dos índios alé mesmo o cercamento de casas - feilas e cobertas com gathos de árvores - $\mathbf{c}$ das poucas incipientes roças yue aprendiam a fazer devido à atuaçāo dos missionários, para evitar que fossem comidas pelo gado. Por outro lado, o boi era um elemento que causava assombro aos índios. Nunca haviam visto um animal de tão grande porte e lão fácil de ser "caçado". Ao Irans formá-los nos novos objelos de suas alividales cconómicas, abriram oulro flanco de conflito com os propriclairios e seus, vaqueiros, tornando a convivencia impossível. As alternalivas que reslaram cram o seu confinamento, uso cumo combatentes, descimenlo para o Reconcavo ou expulsão 
R. IItstórtn, Sío Paulo, n. 129-1.31, p. 179-2018, ngo.-dez./93 a ago.-dez./94.

para as áreas ocupadas por grupos inimigos, onde seriam trucidados $\mathrm{em}$ guerra inter-tribais.

A criaçio exlensiva exigia poucos investimentos iniciais e a mão-deobra usada era composta de livres, que recebiam seu pagamento na base de uma cria para qualro nascidas, após qualro anos efelivos de trabalho, e um lole de terra para o planlio de gêneros alimentícios e a instalação de sua própria fazenda de criação. Era um mecanismo que garantia a constante expansão da área ocupada. Também escravos eram usados nessa atividade $\mathbf{e}$ só, esporadicamente, algum índio aculturado era contratado como vaqueiro.

Moll (1979), ao analisar al colonizaçĩo do Piaú, chama atenção para esses fatos e a meșma realidade pode ser observada nos sertöes baianos, principalmente ao focalizarmos as alividades dos grandes proprietários da regiño: os Guedes de Brito e os Ávila.

Os problemas enlrentados pelos jesuílas não se resumiam às suas aldeias dos "sertōes do norte", onde lambém eram grandes criadores de gado. O enriquecimento da Companhia de Jesus e a abundância māo-de-obra disponível em scus aldeamentos, sua resistênçia em ceder aldeados, quando solicitados, e sun proposta de transformar os aldeamentos em núcleos de conversĩo, criavam ressentimentos e protestos contra seus privilegios e os óbices criados aos projetos dos colonos. Assim, as teis, em determinados momentos, concediam direilos administrallivos exclusivos à Ordem, ora reduzia-nos ou determinavam sua expulsão de vários pontos da colónia.

A sua ação de evangelizaçĩo e aculluração das populações indígenas, que correspondia a outra modalidade de dominação, baseava-se ideologicamente em sentimentos de superioridade racial e cullural, típicos da postura eurocêntrica dos representanles da metrópole, c na crença de serem portadores da verdadeira religião. Exacerbalos pelo fervor missionário, os inacianos adolaram mélodos de aluaçño que conlra riavam os colonos e desestruluravam as culturas indígenas em nome de uma conversão/civilizaçĩo.

Internamente, nos aldeamentos, acumulavam as funçöes dos Karaí e dos Morubixabas, observando as linhas básicas de atuação delerminadas por esses papéis social e culluralmente definidos pelas sociedades indígenas. Usavam as crianças reliradas do convívio familiar como agentes culturais transformadores, violando os valores maiores da organização social tribal, inclusive no tocanle às hierarquizaçōes impostas pelo critério da idade.

No caso Tupi, sua ação vol tava-se para a eliminação da poligamia, da antropofagia, da nudez, das práticas xamanísticas e do nomadismo. A sua administração rígida e o controle efetivo das rotinas de trabalho, levaram ao enriquecimento dos aldeamentos, despérlando a insatisfaçāo dos colonos que não tinham subsílios reais nem infra-estrutura para obter iguais resultados. 
PARAISO, Maria Ililda Baqueiro. De como se obter mão-de-obra índigena na Bahia entre as scculos XVI e XVIII.

Também a fragilidade e o insuccsso dos aldeamentos como núcleos formadores e fornecedores de mão-de-obra. como já afirmamos, haviá desestimulado os colonos a continuarem a apoiar a proposta jesurlica já desde o fim do século XVI, estabelecendo-se o conflito e a dispula entre os dois projelos dissociados. Na conquisıa dos sertöes, os mesmos conflitos vão eslar presentes, criando um clima de contradiçōes que exigia a constanle inlervenção da Coroa como poder moderador.

A virada do século XVIJI não alterou a situaçāo. En 1700, Pedro Gomes França, partindo de llhéus, escravizou os fndios nos rios Jequilinhonha, Pardo, Conlas e Paraguaçu, abrindo a rota entre o rio de Conlas e o norte de Minas Gerais. Esta açĩo na referida írea visava garantir a rota legal de comércio autorizada pela Coroa c foi ampliada em 1712 com a criação de uma série de aldeamentos para os Gren, administrados por capuchinhos, pois eles se recusavam a ser missionados por Jesuílas (SILVA CAMPOS, op. cit: 173-175; 190-192; 202-205).

Novos alaques a Cairu c Jequiriçá implicaram na cessāo de aldeados das missōes ao Capitão-mor Antonio Veloso da Silva. As razōes das revoltas teriam sido os maus tratos, a exploraçāo excessiva do trabalho e a prática de torturas (BORGES DE BARROS, op. cit: 182-183; SILVA CAMPOS, op. cit: 205). Também em Jácobina as revoltas eram constantes, assim como nas minas de salitre no rio homónimo. As queixas não eram apenas contra os índios, mas também cnvolviam a atuaçĩo do capilío-mor, que instalara scus administrados em terra dos grandes latifundiários, dificultando o seu uso pelos pequenos proprietários. Quando os silvícolas se revoltaram por terem sidos instafados em lerras áridas, D. Joño $\mathrm{V}$ delerminou, em carta ao governador Vasco Fernandes Menezes, que o capitão-mor os devolvesse às terras onde antes estavam instalados (AC.IOLY e AMARAL, op. cit: 355).

O uso de aldeados como combatentes tornou-se uma prálica crescente, sendo inclusive, autorizado a capitães-mores yue lhes ministrassem treinamento militar adequado e fornecimento de armas de fogo. A primeira concessāo nesse sentido foi feila ao capitĩo-mor dos Maraćí, que deveria criar uma "muralha do serläo" para proteger as minas de salitre e as feitorias de madeira dos rios Salitre e do Jequiriçá. Os mesmos Maracá foram deslocados para policiarem a rola entre o rio de Contas c o norte de Minas Gerais, evilando os ataques dos grupos ainda não aldeados. Como prêmio, o capitão-mor recebeu uma sesmaria no Jequiriça com direilo a administrar e usar os índios ali aldeados (ACIOLY e AMARAL. op. cit: 355-365).

A prálica crescente da violência no combate áos índios revoltados já havia se instalado em 14/06/1688, quando o Governador Alexandre de Souza Freire havia aulorizado a degola de lodos os homens em "idade da guerra", 
R. Ilbiórta, Słou Paulo, n. 129-j 31, p. 179-208, ago.-dez./93 a ago.-dez./94.

porém intensificou-se a partir de 1726 , quando António Veloso atacou os Maracás que haviam se refugiado entre o Contas e o Paraguaçú. Apenas as mulheres $e$ as crianças foram aprisionadas e levadas para os aldeamento dos Gren no rio Una do Nortc, onde hoje se situa a cidade de Valença. Depois foram transferidas para Palmas, na Chapada Diamantina, objetivando servirem de "iscas" para atrair os poucos homens que tinham sobrevivido ao se refugiarem nas matas.

A mesma tática foi usada por Pedro Leolino Mariz contra os Pataxó, os Kamakã-Mongoió, Gren, Maxakali, e Pañame entre o rio de Contas e o Pardo, que deixava de ser mera rota de comércio para transformar-se em nova área a ser ocupada e explorada. Nesta campanha, aluaram os índios aldeados do Jequiriçá, que receberam armas de fogo; tecidos; munição; anzóis; pedras-de-fogo; pedra-lume; enxofre e sal (BORGES DE BARROS, op. cit: 183).

A violência exercida por Francisco Marques de Oliveira contra os revollosos de Cairu mereceu elogios principalmente por só terem sido cativadas mulheres e criançans, que foram vendidas no Recóncavo. O próprio Rei exigiu, em carta de $18 / 07 / 1733$, que igual tralamento fosse dados aos fugitivos. O Conde de Sabugosa, em seu relatório ao Rei, em 07/01/1734, afirmava que nảo tinha havido preocupação em fazer prisioneiros, mas $\mathrm{em}$ "extinguir a raça" (ACIOLY e AMARAL, op. cit: 167-168; 344).

A tradição de degolar os homens em "idade de guerra" e aprisionar/comercializar mulheres e crianças não se restringia a Capitania da Bahia. Monteiro (op. cit: 1990:14) indica a mesma prálica a referir-se a São Paulo. As razōes eram econômicas, estratégicas e culturais. As econômicas relacionavam-se a melhor adequação das mulheres às atividades agrícolas, por estas já fazerem parte da sua faina tradicional, e à possibilidade dos meninos serem educados nos moldes culturais que atribuíam a eles tais atividades. Porém, preciso que consideremos que nas áreas de sertão, onde a função destinada aos cativos era a de transformarem-se em combatentes, sob o comando dos colonos, ou onde predominavam as atividades de Iransporte e corte de madeira, a preferéncia pelo isabalhador do sexo masculino e adulto predominava. As razōes estratégicas para a preferência por mulheres também se devia à tentativa de reduzir as possibilidades de revoltas entre os aldeados. As culturais, diretamente vinculadas à política de aceteramento da aculturação, vinculava-se a inviabilização da reprodução social do grupo nos moldes tradicionais, inclusive, pelo estímuło aos casamentos interétnicos. Era, porlanto, com a venda de mulheres e crianças na área do Recôncavo, que se ressarciam as despesas de guerra, pagavam-se os impostos, o quinto da Coroa, a "jóia" do Governador, o pagamento dos soldados, cabos e oficiais 
PARAISO, Maria Ililda Bryuetro. De como se obter māo-de-ubra indgena na Bahia entre os seculus XVle XVIII.

da entrada, conforme determinação da Carta Régia de 25.10.1707 (PERRONE-MOÍSES, op. cit: 127).

A Bula de $20 / 12 / 1741$ de Benedito XIV vollava a proibir a escravidäo indígena, sob qualquer pretex10. As reaçōes no Brasil foram da desobediência, uma decisão do Bispo do Pará até decidiu suspender os efeitos punilivos previstos, assustado com as reaçōes.

Novas revoltas continuavam entre os índios da Bahia: em 1746, os Paiaiá atacaram a vila e as minas Je Jacobina; em 1749, os Gren assaltaram Cairu e em 1750 Camamu. Os próprios moradores da vila se encarregaram da repressão, além de exigirem a nomeação de Capitāes-Mores e da Conquista c do uso dos aldeados para garantir-lhes a proleção necessária (ACIOLY e AMARAL, op. cit: $177-299$ ).

As relações eslabelecidas, nesse perfodo, podem ser caracterizadas como violenlas e voltadas, para numa primeira etapa, para șubstituir os dizimados Tupi pelos indesejados Tapuias. Posteriormente, a guerra contra esses grupos assume o caráler de conquista de novos espaços para a expansão da atividade pecuária.

Outra característica é a de que as populações indígenas adotam um papel bem mais reativo à penetração e a escravização, criando um quadro de sucessivas revoltas e ataques a vilas e povoações, estimulando a intensificaçăo da prática guerreira, que gerou mais reaçôes e mais puniçōes:

Esse quadro de conflito generalizado preocupava a Coroa que não mais conseguia fazer respeilar os parâmelros gerais de sua política: o estabelecimento c a manutençäo de alianças com grupos indigenas considerados como essenciais à segurança da colónia. Essa preocupação vai se acenluar no reinado de D. José I, sob a inspiraçĩo de seu ministro, o Marquês ue Pombal, que via nos índios os povoadores dos espaços coloniais c que precisavam sentir-se como súditos portugueses para evitar o possível avanço espänhol nás fronteiras.

\section{$V I$ - Conchusöes}

Contrariamente ao que se propaga, o trabalho indígena foi de alta relevância para o sucesso do projeto de ocupaçāo e colonização do Brasil. Esla verdade pode ser inferida da profusa legislação sobre o assunto e pelo conjunto de açōes e reaçōes dos vários segmentos sociais: administradores reais, missionários, colonos e inúmeros grupos indígenas.

Entre os séculos XVI e XVIII, como se pode constatar, a grande preocupação residia na definição das formas compulsórias de incorporação de mão-de-obra indígena. A questão da expropriação de terra era marginal e 
R. llistórta, S7̋o Paulo, n. 129.1.31, p. 179-208, ago.-dez./93 a ago.-dez/94.

decorria da prálica de aldear e promover descimentos, que, automalicamente, liberavam parcelas dos terrilórios tribais para os colonos.

O eixo da polílica calcava-se na dupla categorização dos grupos indegenas - "mansos ou hostis" -, nas formas adotadas pelas relaçōes interétnicas e nas tentalivas de conciliação entre interesses e projetos opostos que a Coroa procurava adminislrar em nome de un fim maior e menos imediatisla: a promoção da cfetiva ocupação e colonização.

Como conseqüência, as formas de apropriação do trabalho indígena foram diferentes a de depender do ponto de inserção do grupo no conjunto das relações e polílicas estabelecidas.

Os "mansos/aldeados/aliados" trabalhavam nas roças dos aldeamenlos, produzindo géneros alimenlícios comercializados pelos administradores particulares ou missionários; nas propricdades particulares de forma compursória e por tempo determinado, recebendo tecidos como forma de pagamento; como guias e estimuladores de descimentos; como intérpretes nos contactos com os grupos nāo conhecidos; como defensores da colónia, em casos de ataques de franceses, holandeses ou ingleses e de tribos hostis, e, finalmente, em obras públicas determinadas pelos agentes administralivos da Coroa. É importante ressaltar que a maioria desses Irabalhos eram exercidos fora do perímetro da aldeia e dos aldeamentos, o que implicava na aceleraçî́o do processo de desestruturação económica e social do grupo, dificultando a reprodução física e social do grupo.

As tálicas usadas para manter os aldeamentos providos de mão-deobra, apesar das altíssimas taxas de morlalidade, era a promoção de descimentos e o assentamento de novos aldeados nas proximidades das vilas c engenhos, onde trabalhavam, além de protegê-los.

Eram tornados sedentários em áreas que desconheciam e, até quando os recursos nạturais necessários à prática da caça e coleta, essenciais, mesmo para os grupos agricultores, se esgotavam, viam-se impossibilitados de buscarem alternativas de suprimento alimentar. Is to os tornava, crescentemente dependentes de colonos. Essa subordinação e vinculação aos interesses do projeto colonial esı́ explicitada, por exemplo, no Regimento das missões de 1686: "(...) que hajam nas ditas aldeias índios que possam ser bastantes, tanto para a segurança do Estado e defesas das cidades, como para o trato e serviço dos moradores e entradas dos sertões (...)" (apud PERRONE-MOÍSES, op. cit: 120 ). Os "bravios/errantes/inimigos" recebiam o tratamento previsio nas leis que regulamentavam as Guerras Justas: escravizaçāo, distribuição entre os organizadores das Expediçōes, venda em hasıa pública; descimentos forçados e uso indiscriminado nas atividades que fossem consideradas convenientes e necessárias. 
PARAISO, Maria Ifilda Baqueiro. De como se ubter mão-de-ubra indigena na Bahia entre as seculus XVI e XVIII.

A política de aldeamento compulsório deve ser analisada pelo angulo das conveniências econômicas, estratégicas, polílicas e culturais. No campo economico as vantagens eram: Lacilitar o acesso no contingente de trabalhadores, racionalizar a aplicação de recursos necessários a sua adminis traçīo e liberaçāo de terras para efetiva ocupação pelos colonos. Em termos estratégicos, o assentamento em locais adequados permitia seu uso como eficientes "barreiras do sertão", além de facilitar a repressão nos momentos de revolta dos aldeados. Em termos polílicos e cullurais, a concentração numa ́írea restrita facililava a aluação dos agentes colonizadores na promoção da conversāo/aculluração/incorporação dos inclígenas ao modelo previsto pelá administração curopéia (CUNHA op. cit: 143).

Os limites do modelo escravista indígena eram dados pela dificuldade de manter o numero ideal de trabalhadores devido à alta laxa de mortalidade c à instabilidade no suprimento externo. Também o número elevado de revollas e fugas era considerado como dificulıador da manulenção do sistema. Finalmente, as crescentes distancias a serem percorridas para garantir o abastecimento, a maior resistência dos grupos Macro-Jê à escravizaçĩo, à sedentarizaçâo e à agricultura, tornavam o empreendimento cada vez menos lucrativo.

Essas dificuldades, se comparadas com as facilidades de obtenção e uso dos escravos negros, fizeram com que estes se tornassem a opçāo preferencial dos colonos capitalizados (SCHWARTZ, op. cit: 52; 57-73)

Porém, diferentemente Jesse autor, não acredilamos que a substituição da mão-de-obra indígena pela africana tenha ocorrido com a rapidez que ele alega, mesmo no Recóncavo. Para os pequenos proprietairios e os produtores voltados para o mercado regional, o Irabalho indigena era essencial, inclusive para se capitalizarem e poderem substituir uma força de Irabalho por outra. Outro argumento que consideramos indicativo dessa importancia, já na melade do século XVIll, é a preocupação do Marquês de Pombal $\mathrm{cm}$ garanlir tormas de apropriação do trabalho indigena pelos colonos e que, apesar de encobertos, como dizia Joảo Lúcio de Azevedo" (...) sob a forma falaz de liberdade (...)" (apud DORNAS, op. cit: 24), se caracterizavam pela violência.

\section{Referências Bibliograficas}

ACIOLY, J e AMARAL, B. Memórias Históricas e Políticas da Bahtia. Salvador: Imprensa Oficial do Estado, 1925.

ALENCASTRO, L. F. A Intereaç̧âo Européia com as Suciedades Brasileirns Entre Séculos XVI e XVIII. In Brasil nas Vésperas do Muindo Moderno. Lisbon: Comissaño Nacional para as Comemoraçōes dos Descobrimentos Portugueses, 1992. 
R. Ilstírì, Sau Paulo, n. 129-131, p. 179-208, ago.-dez./93 a ngo.-dez./94.

BORGES DE BARROS, F. A Confederaçio dox Índios Gren: 1508. In Amais do Arpuiio Público e Museu do Estado da Batia. Silvador: Imprensa Oficial do Estado; s/d (4-5).

BOXER, C. R. Salıador de Sá e a huta pelo Brasil e Angola. São Paulo: Cia. Editora Nacional, 1973.

CUNHA, M. M. C. da. Legislaçno Indigenista no Século XIX. São Paulo: Comissão Pro-Índio de São Paulo/Edusp, 1992.

DANTAS, B. et alli . Os Povos Indígenas no Nordeste Brasileiro: Um Esboço llistórico. In ClINHA, M. M. C. da. História dos fndios no Brnsil. Săo Paulo: Cia de Letras da Bahia, Fapesp, SMC, 1992.

DAVIS, B. D. El Problema de la Esclavitud en Ia Sociedad Ocidental, Buenos Aires: El. Paidos, 1968.

DORNAS FILHO. A Escrnidāo no Brasil. Rio de Janeiro; Ed Civilização Brasileira, 1939.

HEMMING, J. The Red Gold: The Conquest of Brazilian Indians. London: Macmillan London Limiled; 1978

MALHeIROS, P. A Escravidão no Brasil Ensaio Hisiorico - Jurfdico-Social. São Paulo: Ed. Cultura, 1944.

MARIANI, J B de A. Povoamento da Bahia - Século XVI. In Revista do Centro de Estudas Baiamos. Salvador: UFBA, 1971.

MONTEIRO, J. As populaçúes Indígenas do Litoral Brasileiro do Século XVI: Iransformaçōes e Resislência. In O Brasil nas Vesperras to Mundo Moderno. Lisbon: Comissío Nacional para as Comemoraçües dos Descubrimentos Portuguses, 1992.

MONTEIRO, J. O Sertanismo e a Criaçĩo de Uma Força de Trabalho. In O Brasil uas Vesperas do Mundo Moderno. Lisboa: Comissâo Nacional para as Comemornçóes dos Descobrimentos Portugueses, 1992.

MONTEIRo, J. Os Escravos f́ndios de São Paulo no Século XVIl: Alguns Aspectos Demográficos. In Revista da SPBH. São Paulo: SBPH(V), 1990, pp. 13-18.

MOTT, L. R. B. Os Indios e a Pecuária nas Fazendas de Gado do Piaú Colonial. In Revista de Antropologia. São Paulo: Edusp, 1979.

OTT, C. A Distribuiçăo tribal e Geográfica dos Índios Baianos. In AGOSTINHO, P (org) Revista Cultura - O Indio na Baltia. Salvador: Fundaçīo Cultural do Estado, 1988.

PARAiso, M H B . Os Botocudos e sua Trajetória Histórica. In CUNHA, M M C da (org) História dos Indios no Brasil. Sāo Paulo: Cia das tetras, Fapesp, SMC, 1992.

PaRAíso, M. H. B. Os Kiriti Sapuyá de Pedra Branca. In Revista do Centro de Estudos Bahiarios. Salvador: UFBA, 1985.

PERRONE MOISÉS, B. Índios Livres e Indios Escravos: Os Princípios da Legistaçז̃o Indigenista no Período colonial in CUNHA, MMC (org) Histórico dos Índios no Brasil, Sño Paulo: Cia das Letras, Fapesp, SMC, 1992.

PINTO, J. da R. O Olhar Europeu: a Invençño do ndio Brasileiro In $O$ Brasil uas Vesperas do Mundo Moderno. Lisboa: Comissfo Nacional para Comemorações dos Descobrimentos Portugueses, 1992.

RoMANO, R. Mecanismo de Conquista Colonial. São Paulo: Editorn Perspectiva S/A, 1989.

SCHWARTZ. Segredos Intermos: Engenhos e Escravos na Sociedade Colonial 1500-18.35. Sáo Paulo: Cia das Letras/CNPq, 1988. 
PARAfSO, Maria llilla Bayueiro. De como se ubter mão-de-obra indígena na Bahia entre us séculos XVI e XVIII.

SILVA CAMPOS. Crônica da Capitania de Ilhéus. Bahia: Imprensa Vitórin, 1947.

SOUTHEY, R. Historia do Brasil. São Paulo: Cia. Ed. Melhoramentos/MEC, 1977.

URBAN, C. R. ^ História da Cultura Brasileira segundo as Línguas Nativas. In CUNHA, M. M. C. da. (org). História dos Indios no Brasil. Sáo Paulo: Cia das Letras, Fapesp, SMC, 1992.

VOLPATO. Entradas e Bandeiras. Sāo Paulo: Ed. Global, 1985.

ABSTRACT: The article is an analysis of the policies toward the indians, the proctices used in the captaincies of Bahia, llbeus, and Porto Seguro between the 16th and 17th century, and the altempts to appease the conflicting interests of indigenous groups, settlers, jesuits, and metropolitan administrators. This study demonstrates how the social relationships which were established resulted from visions, interests, cultural references, values, and social strategies of the various parls involved and how these diversities were articulated, creating a complex social network related to the various projects dealing with the effective ocupation and exploitntion of the new colony.

KEY-WORDS: Colonial Period, Bahia, Indigenous Policy, Indigenous Inbor, Indigenous slavery. 